\title{
Virologic and Immunologic Outcomes in Patients Switched from Amprenavir to Fosamprenavir in a Clinical Practice Setting
}

\author{
Joseph C. Gathe ${ }^{1}$, Benjamin Daquoiag ${ }^{1}$, John E. Fuchs² and Gary E. Pakes ${ }^{2 *}$
}

${ }^{1}$ Private Practice, Houston, TX, USA

${ }^{2}$ GlaxoSmithKline, Research Triangle Park, NC, USA

\begin{abstract}
In a 24-week phase 4, non-randomized, open-label, single-arm study, 19 HIV-infected patients receiving amprenavir (APV)-based highly active antiretroviral therapy (HAART) for 1.3-4.2 years (mean, 3.1 years) were switched to equimolar fosamprenavir (FPV) doses with no other changes in their treatment regimens. Most patients $(74 \%)$ received APVI ritonavir $600 \mathrm{mg} / 100 \mathrm{mg}$ twice daily at screening. All but one were switched to FPV/ritonavir $700 \mathrm{mg} / 100 \mathrm{mg}$ twice daily. Between baseline and week 24 after switching, clinical status generally remained stable or improved: median viral load 751 vs 71 copies $/ \mathrm{mL}$; CD4+ count 570 vs $622 / \mathrm{mm}^{3}$; proportion with viral load $<400 \mathrm{copies} / \mathrm{mL} 47 \%$ vs $71 \%$, and $<50$ copies $/ \mathrm{mL}, 32 \%$ vs $35 \%$. In 13 patients whose baseline HIV-1 RNA was $>50$ copies $/ \mathrm{mL}$, eight remained at this level and three were below it at week 24 (the other two were lost to follow-up). No study drug-related adverse events were reported and laboratory values did not notably change.
\end{abstract}

\section{Introduction}

Since the introduction of protease inhibitors (PI) in highly active antiretroviral therapy (HAART) for HIV infection in the mid-1990s, HIV-related morbidity/mortality has decreased to one-fifteenth the level observed prior to the HAART era $[1,2]$. Amprenavir, the fourth PI to become available, offered some advantages over earlier PIs, including the option for once- or twice-daily dosing, minimal effect of food on its pharmacokinetics and a favorable resistance profile $[3,4]$. However, APV's low aqueous solubility necessitated a large, cumbersome capsule formulation containing propylene glycol and vitamin $\mathrm{E}$ as solvents and APV administration involved a high pill burden (16 capsules daily for unboosted treatment in adults), both of which could negatively impact adherence.

Research efforts to reduce the pill burden of APV delivery while retaining APV's dosing flexibility led to the development of fosamprenavir (FPV), the more water-soluble calcium phosphate ester prodrug of APV. An oral dose of $700 \mathrm{mg}$ of FPV is equimolar to APV $600 \mathrm{mg}$ [5]. FPV is rapidly hydrolyzed to APV and inorganic phosphate as it is absorbed through the gut epithelium. A daily regimen of unboosted FPV requires that the patient take only four 700-mg tablets daily, which is less than one-quarter the pill burden associated with an equimolar unboosted APV daily regimen. Subsequent clinical trials with FPV combined with a nucleoside backbone confirmed its clinical value in both antiretroviral naïve- and -experienced patients [6-10].

As patients stabilized on APV are currently being switched to FPV in HAART regimens (as the capsule formulation of APV is being discontinued in most countries), it is important to evaluate if and how this switch affects treatment response and the patients' clinical status. The purpose of the present study was to assess over 24 weeks virologic and immunologic response and treatment tolerability in antiretroviral-experienced patients who switched from APVcontaining HAART regimens to regimens containing equimolar doses of FPV with no other changes in their regimens.

\section{Materials and Methods}

COL101310 was a phase 4 , non-randomized, open-label, singlecenter study for which the inclusion criteria were as follows: male or non-pregnant, non-breastfeeding female $\geq 18$ years old,
HIV-1 infection documented by HIV-1 antibody enzyme-linked immunosorbent assay (ELISA) and Western blot test; any HIV-1 RNA level and CD4+ cell count; not currently receiving other PIs; and not enrolled in any other clinical trial of an investigational agent. The APV component of regimens was replaced by an equimolar dose of FPV, as shown in (Table 1) and patients were followed for 24 weeks. No change in the type or dose of any other antiretroviral regimen component was permitted.

At screening, weeks 6, 12 and 24 and withdrawal, assessments were made of plasma viral load (HIV-1 RNA) using Roche Amplicor MONITOR Ultrasensitive assay, Version 1.5 (lower limit of quantitation

\begin{tabular}{|c|c|c|}
\hline & APV regimen & FPV regimen \\
\hline \multirow[t]{3}{*}{$\begin{array}{l}\text { Patients who received } \\
\text { APV as first their PI }\end{array}$} & $\begin{array}{c}\text { APV } 1200 \mathrm{mg} \mathrm{BID} \mathrm{+} \\
\text { SBG }\end{array}$ & $\begin{array}{c}\text { FPV } 1400 \text { mg BID (or FPV } \\
700 \text { mg + RTV 100mg BID) } \\
+ \text { SBG }\end{array}$ \\
\hline & $\begin{array}{c}\text { APV } 600 \mathrm{nmg}+\mathrm{RTV} \\
100 \mathrm{mg} \text { BID + SBG }\end{array}$ & $\begin{array}{c}\text { FPV } 700 \mathrm{mg}+\mathrm{RTV} 100 \mathrm{mg} \\
\text { BID + SBG }\end{array}$ \\
\hline & $\begin{array}{l}\text { APV } 1200 \mathrm{mg}+\mathrm{RTV} \\
200 \mathrm{mg} \text { QD + SBG }\end{array}$ & $\begin{array}{l}\text { FPV } 1400 \mathrm{mg}+\mathrm{RTV} 200 \mathrm{mg} \\
\text { QD) or FPV } 1400 \mathrm{mg}+\mathrm{RTV} \\
200 \mathrm{mg} \text { QD (or FPV } 700 \mathrm{mg} \\
+ \text { RTV } 100 \mathrm{mg} \text { BID) + SBG }\end{array}$ \\
\hline \multirow{2}{*}{$\begin{array}{l}\text { Patients who received } \\
\mathrm{APV} \text { as their second } \\
\text { or third } \mathrm{PI}\end{array}$} & $\begin{array}{c}\text { APV } 1200 \mathrm{mg} \text { BID + } \\
\text { RTV 200mg QD + SBG }\end{array}$ & $\begin{array}{c}\text { FPV } 700 \mathrm{mg}+\text { RTV } 100 \mathrm{mg} \\
\text { BID + SBG }\end{array}$ \\
\hline & $\begin{array}{l}\text { APV } 600 \mathrm{mg}+\mathrm{RTV} \\
100 \mathrm{mg} \text { BID + SBG }\end{array}$ & $\begin{array}{c}\text { FPV } 700 \mathrm{mg}+\mathrm{RTV} 100 \mathrm{mg} \\
\text { BID + SBG }\end{array}$ \\
\hline
\end{tabular}

a Abbreviations: APV, amprenavir; BID, twice daily; FPV, fosamprenavir; QD, once daily; RTV, ritonavir.

Table 1: Initial APV Regimen and the FPV regimen to which Patients were Switcheda.

*Corresponding author: Gary E. Pakes, U.S. Collaborative Studies, ID MDC-HIV GlaxoSmithKline, 5 Moore Drive, Research Triangle Park, NC 27709, USA, Tel: 919-483-8242; Fax: 919-315-6029; E-mail: gary.e.pakes@gsk.com

Received October 04, 2010; Accepted December 07, 2010; Published Decembe 08, 2010

Citation: Gathe JC, Daquoiag B, Fuchs JE, Pakes GE (2010) Virologic and Immunologic Outcomes in Patients Switched from Amprenavir to Fosamprenavir in a Clinical Practice Setting. J AIDS Clinic Res 1:109. doi: $10.4172 / 2155-6113.1000109$

Copyright: ( 2010 Gathe JC, et al. This is an open-access article distributed under the terms of the Creative Commons Attribution License, which permits unrestricted use, distribution, and reproduction in any medium, provided the original author and source are credited. 
Citation: Gathe JC, Daquoiag B, Fuchs JE, Pakes GE (2010) Virologic and Immunologic Outcomes in Patients Switched from Amprenavir to Fosamprenavir in a Clinical Practice Setting. J AIDS Clinic Res 1:109. doi:10.4172/2155-6113.1000109

Page 2 of 4

\begin{tabular}{|l|l|l|l|l|l|l|l|l|}
\hline Patient No. & Baseline & \multicolumn{3}{l}{ Week 6 } & Week 12 & Week 24 \\
\hline & VL & CD4+ & VL & CD4+ & VL & CD4+ & VL & CD4+ \\
\hline 1 & 180,000 & 325 & 399 & 299 & 4,670 & 288 & 6,150 & 367 \\
\hline 2 & ND & ND & 49 & 524 & 49 & 738 & 59 & 990 \\
\hline 3 & 1,040 & 440 & 1,510 & 359 & 49 & 423 & 152 & 316 \\
\hline 4 & 492 & 788 & 1,630 & 624 & 49 & 518 & 695 & 868 \\
\hline 5 & 3170 & 934 & 2,250 & 922 & 1.600 & 959 & $60,200^{\mathrm{b}}$ & 503 \\
\hline 6 & 399 & 268 & MV & MV & 78 & 292 & 84 & 268 \\
\hline 7 & 1,540 & 247 & 511 & 273 & 3,760 & 299 & LTFU & LTFU \\
\hline 8 & 3,370 & 1699 & 1,160 & 1472 & 49 & 804 & 2,370 & 653 \\
\hline 9 & 399 & 617 & 546 & 670 & MV & MV & 233 & 618 \\
\hline 10 & 49 & 160 & 49 & 456 & 572 & 532 & 544 & 532 \\
\hline 11 & 49 & 292 & 49 & 197 & 49 & 238 & 49 & 490 \\
\hline 12 & 49 & 571 & 284 & 612 & 51 & 203 & 55 & 690 \\
\hline 13 & 49 & 1056 & 49 & 1277 & 1,340 & 1193 & 49 & 1462 \\
\hline 14 & 1,410 & 967 & 909 & 906 & 515 & 647 & 71 & 955 \\
\hline 15 & 49 & 568 & 49 & 484 & 49 & 447 & 49 & 517 \\
\hline 16 & 18,800 & 292 & MV & MV & 2,640 & 143 & LTFU & LTFU \\
\hline 17 & 1,100 & 679 & 89 & 561 & 109 & 507 & 49 & 896 \\
\hline 18 & 52 & 449 & 416 & 528 & 101 & 509 & 49 & 622 \\
\hline 19 & 1,010 & 1049 & 673 & 1144 & 49 & 1102 & 49 & 1134 \\
\hline & & & & & & & & \\
\hline Median & 751 & 570 & 416 & 561 & 90 & 508 & 71 & 622 \\
\hline Mean & 13,264 & 633 & 625 & 665 & 877 & 547 & 4171 & 699 \\
\hline
\end{tabular}

aAbbreviations: LTFU, lost to follow up; MV, missed visit to clinic; ND, laboratory values not done; VL, viral load.

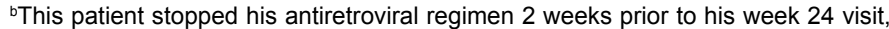
and this lead to a marked viral rebound.

Table 2: Viral Load Change (copies/mL) and CD4+ Cell Count (Cells $/ \mathrm{mm}^{3}$ ) in Each Patient following Switch from Amprenavir to Fosamprenavira

\section{A}

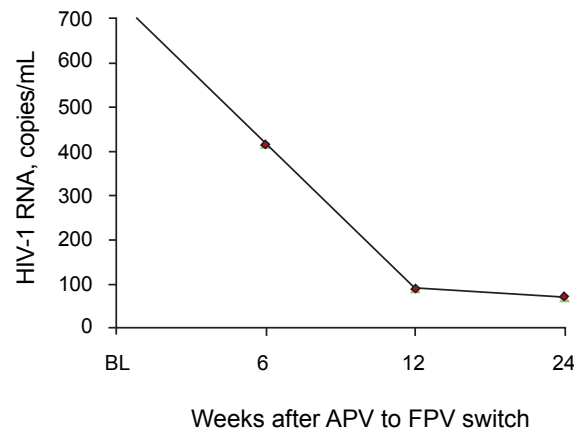

B

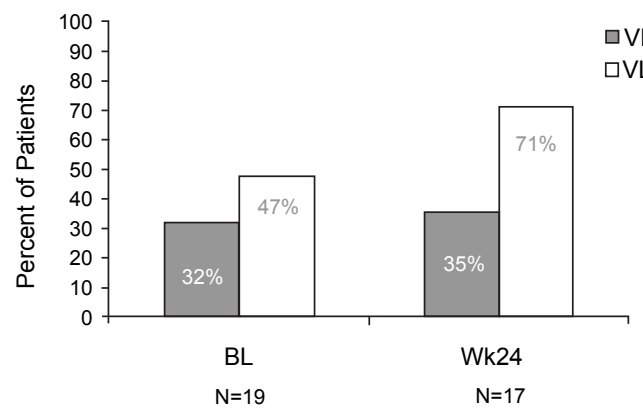

Figure 1: Median plasma HIV-1 RNA concentrations over the 24-week period following switching from amprenavir to fosamprenavir (A), and proportion of patients with viral loads $<400$ and $<50$ copies $/ \mathrm{mL}$ at baseline (BL) and week 24 (B).

[LLOQ] 50 copies/mL; Roche Diagnostics, Branchburg, New Jersey) and HIV-1 MONITOR Version 1.0 polymerase chain reaction (PCR) assay (LLOQ, 400 copies/mL; Roche, Nutley, New Jersey). At these time points, the following were also assessed: CD4+ cell count by flow cytometry, adverse events by open-ended questions posed to the study patients and standard laboratory tests. Patients who never

achieved a viral load $<400$ copies/mL or who achieved it during treatment but lost it by week 24 were considered virologic failures.

FPV was administered as 700-mg tablets of Lexiva ${ }^{\circledR}$ (GlaxoSmithKline, Research Triangle Park, NC) and ritonavir as 100mg capsules of Norvir ${ }^{\circledR}$ (Abbott Laboratories, Chicago, Illlinois). Adherence was checked by pill counts made by study personnel. In virologic failures, drug-susceptibility phenotype was assessed by ViroLogic Inc. (South San Francisco, California, USA) using the GENESEQ and the PHENOSENSE assays. Statistical analysis of the study results was primarily descriptive. However, the Wilcoxon signed-rank test was used to test whether the median change from baseline of $\log _{10}$ HIV-1 RNA at week 24 was zero. The significance of change in CD4+ cell count between baseline and week 24 was analyzed by the non-parametric paired Wilcoxon test.

\section{Results}

Nineteen patients were enrolled in the study, including 18 males and 1 female. Twelve patients were African American, six white and one Hispanic. Mean duration of APV use was 3.1 years (range, 1.34.2 years). Most patients (14 [74\%]) received APV/r 600mg/100mg BID. Baseline median viral load was 751 copies/mL (range 49-180,000 copies/mL). Forty-seven percent of patients (9) had HIV-1 RNA $<400$ copies/mL, of whom six $(32 \%)$ were $<50$ copies $/ \mathrm{mL}$. Median CD4+ count was $570 / \mathrm{mm}^{3}$ (range, $160-1699 / \mathrm{mm}^{3}$ ). Seventeen patients completed the study and two were lost to follow-up.

Change in viral load over the study is shown in (Table 2) and (Figure 1A). The median change from baseline in $\log _{10}$ HIV-1 RNA at week 24 for the 16 patients with paired samples was a decrease of $0.09 \log _{10}$ copies $/ \mathrm{mL}$, a difference that was not statistically significant $(p=0.11)$. However, for the 10 patients who were detectable at baseline ( $>52$ copies $/ \mathrm{mL}$ ), the median change from baseline was a statistically significant decrease of $0.76 \log _{10}$ copies $/ \mathrm{mL}(\mathrm{p}=0.04)$.

With respect to proportions of patients achieving undetectable viral loads, a greater proportion had HIV-1 RNA $<400$ copies $/ \mathrm{mL}$ (71\% [12/17]) at week 24 compared with baseline (47\% [9/19]) (Figure 1B). Of the nine patients whose HIV- 1 RNA was $<400$ copies/mL at baseline, eight remained at this level and one was $>400$ copies $/ \mathrm{mL}$ at week 24 . Of the 10 patients whose HIV-1 RNA was $>400$ copies $/ \mathrm{mL}$ at baseline, four remained at this level and four were $<400$ copies $/ \mathrm{mL}$ by week 24 , with two lost to follow-up.

A similar proportion of patients had HIV- 1 RNA $<50$ copies/mL at week 24 (35\% [6/17]) compared to baseline (32\% [6/19]) (Figure 1B). Of the six patients who had $<50$ copies $/ \mathrm{mL}$ at baseline, three remained at this level over the study period and three had an HIV-1 RNA $>50$ copies/mL at week 24 . Of the 13 patients whose HIV-1 RNA was $>50$ copies $/ \mathrm{mL}$ at baseline, eight remained at this level and three were $<50$ copies/mL at week 24 , with two patients lost to follow-up. Only one patient whose baseline viral load was $<50$ copies had a viral load $>400$ copies $/ \mathrm{mL}$ at week 24 (544 copies/mL).

Median CD4+ counts increased by +52 cells $/ \mathrm{mm}^{3}$ (from $570 / \mathrm{mm}^{3}$ at baseline to $622 / \mathrm{mm}^{3}$ at week 24); there was only slight fluctuation over time and no significant change between baseline and week 24 $(p>0.05)$ (Figure 2). No study drug-related or significant adverse events were reported and no significant changes in laboratory values occurred. Figure 3 depicts the changes in median lipid values. No clinically important changes in total cholesterol, LDL-cholesterol, HDL-cholesterol, or triglycerides were observed over 24 weeks postswitch. The largest fluctuations in lipids were seen with triglycerides 


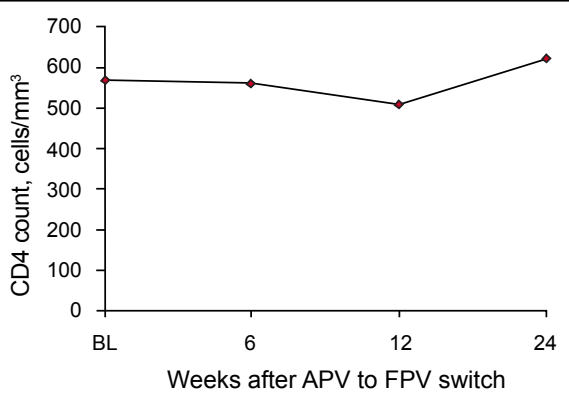

Figure 2: Changes in CD4+ cell count over the 24 weeks after switching from amprenavir (APV) to fosamprenavir (FPV)

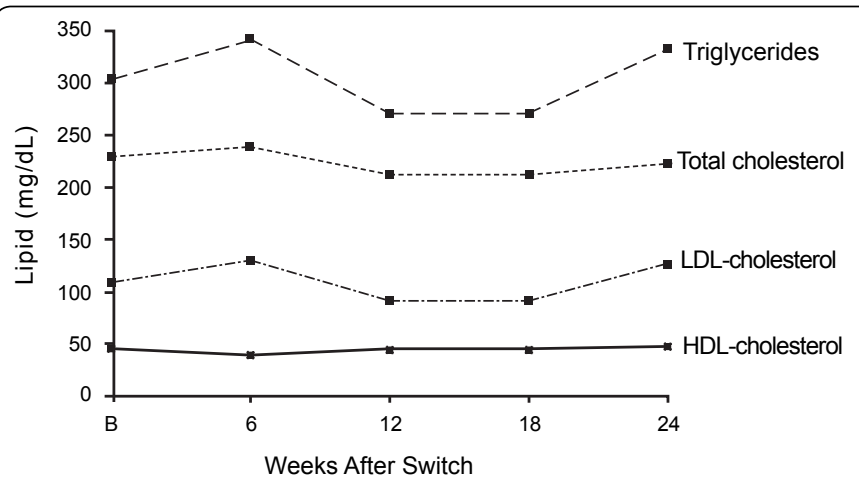

Figure 3: Changes in plasma lipid concentrations over the 24 weeks after switching from amprenavir to fosamprenavir.

and LDL-cholesterol, with variations of $\pm 30-60 \mathrm{mg} / \mathrm{dL}$ and $\pm 20-40$ $\mathrm{mg} / \mathrm{dL}$, respectively, between each 6-weekly clinic visit through week 24

\section{Discussion}

The results of this study show that in patients switched from equimolar doses of APV to FPV in HAART regimens with no other regimen changes, virologic suppression is maintained or improves and CD4+ counts increase over 24 weeks. Although we did not perform any pharmacokinetic assessment in this study, the FPV-containing regimens to which patients were switched were expected to provide an APV area under the plasma concentration-time curve (AUC) similar to that achieved by the patients' prior APV-containing regimens, based on the findings of a pharmacokinetics study, APV20001 [11]. In the latter randomized, crossover pharmacokinetic study in 78 HIVinfected patients, FPV $1395 \mathrm{mg}$ BID and APV $1200 \mathrm{mg}$ BID, each in combination with abacavir $300 \mathrm{mg}$ BID and lamivudine $150 \mathrm{mg}$ BID, delivered equivalent steady-state values for APV AUC at the end of a dosing interval $(\tau)$, although the minimum APV plasma concentration $\left(C_{\min }\right)$ was $28 \%$ higher and maximum APV plasma concentration $\left(C_{\max }\right)$ was $30 \%$ lower than what was seen with the APV regimen. In our study, it is possible that a higher APV $\mathrm{C}_{\min }$ with the FPV regimen may have accounted for the greater proportion of patients achieving HIV-1 RNA $<400$ copies/mL following the switch. A higher APV $\mathrm{C}_{\text {min }}$ could have ensured APV plasma concentrations more consistently maintained above the $50 \%$ inhibitory concentrations of at least wildtype HIV isolates.

Adherence was monitored by pill count in this study. As we had no pre-study adherence information, we could not determine whether adherence was different during FPV treatment compared to prior APV treatment. However, another clinical trial, CLASS (ESS40001) [12,13], did monitor adherence by a self-administered adherence questionnaire, PMAQ-7 [14], in patients switching from APV to equimolar doses of FPV with an abacavir/lamivudine nucleoside backbone. Sixty-six patients were followed for a median of 175 days on APV and 570 days on FPV. PMAQ-7 results showed no overall difference in adherence between the APV and FPV study phases, although patients reported greater satisfaction with FPV treatment than APV treatment. Seventy-nine percent of the study patients who had a viral load $<400$ copies/mL prior to the APV-toFPV switch maintained this level of viral suppression while on FPV.

Patients in our study reported no change in treatment tolerability following the APV to FPV switch, an observation also noted among the treatment-experienced patients in CLASS [13]. In general, treatment-experienced patients may not detect important changes in regimen tolerability because they frequently gain tolerance to certain adverse events over time, especially those affecting the gastrointestinal tract [14]. In contrast, studies in antiretroviral-naïve subjects that have directly compared equimolar FPV and APV have reported a considerably better gastrointestinal safety profile with the FPV regimens. Thus, in the healthy subjects in APV10022, FPV $700 \mathrm{mg}$ BID plus RTV $100 \mathrm{mg}$ BID was associated with one-fifth the rate of nausea ( $6 \%$ vs $33 \%$ ) and half the rate of vomiting and abdominal pain (6\% vs $13 \%$ ) over a 14 -day dosing period [16]. Similarly, in APV20001, which directly compared FPV $1395 \mathrm{mg}$ BID plus abacavir/lamivudine with APV $1200 \mathrm{mg}$ BID plus the same nucleoside backbone, the FPV regimen was associated with a lower frequency of nausea (4\% vs $22 \%$ ) and abdominal pain ( $4 \%$ vs $17 \%$ ) [11]. Better GI tolerability with FPV, where observed, could in part be explained by the lower bulk/ pill count associated with FPV dosing compared to APV dosing and possibly to the lower APV $\mathrm{C}_{\text {max }}$ 's that result following FPV doses.

No important lipid changes were noted following the APV to FPV switch. This is consistent with a similar finding noted in CLASS following an equimolar switch from APV to FPV [12]. It is also expected by the lack of clinically important differences in lipid changes observed over 4 weeks when equimolar doses of APV and FPV were directly compared [11]. The considerable fluctuations in triglycerides and LDL-cholesterol we observed after the APV-to-FPV switch were likely related to temporary alterations in diet and/or physical activity by the patients during the study (not monitored), rather than to treatmentrelated reasons because changes in components of antiretroviral regimens or in antihyperlipidemics were not made.

The design of our study was limited by the absence of inclusion of MEMS adherence measures, plasma APV assessments, resistance measurements and a quality-of-life evaluation before and after the switch to the FPV regimens. However, improvement has been reported previously in one quality-of-life measurement in CLASS following an APV to FPV switch [12]. A large number of studies have shown that the degree of $\mathrm{T}$ cell activation predicts disease progression better than either viral load or peripheral blood CD4 $+\mathrm{T}$ cell counts (using classical markers such as HLA-DR, CD38 and Ki-67) [17-20]. It would be interesting to see how an APV-to-FPV switch impacts levels of CD4+ and $\mathrm{CD} 8+\mathrm{T}$ cell activation and/or proliferation using such classical markers. This type of study needs to be explored in future clinical trials of patients converting from APV-based to FPV-based regimens.

In conclusion, in treatment-experienced patients switched from APV- to FPV-containing HAART, virologic suppression was maintained or improved and CD4+ counts increased over the ensuing 24 weeks, without drug-related adverse events or worsening laboratory values. 
Citation: Gathe JC, Daquoiag B, Fuchs JE, Pakes GE (2010) Virologic and Immunologic Outcomes in Patients Switched from Amprenavir to Fosamprenavir in a Clinical Practice Setting. J AIDS Clinic Res 1:109. doi:10.4172/2155-6113.1000109

\section{Acknowledgments}

The authors would like to thank the patients who participated in this study and the staff at Dr. Gathe's private infectious disease practice in Houston, Texas for making this study possible.

\section{References}

1. Mocroft A, Ledergerber B, Katlama C, Kirk O, Reiss P, et al. (2003) Decline in the AIDS and death rates in the EuroSIDA study: an observational study. Lancet 362: 22-29.

2. Gandhi T, Wei W, Amin K, Kazanjian P (2006) Effect of maintaining highly active antiretroviral therapy on AIDS events among patients with late-stage HIV infection and inadequate response to therapy. Clin Infect Dis 42: 878-884.

3. Goodgame JC, Pottage JC Jr, Jablonowski H, Hardy WD, Stein A, et al. (2000) Amprenavir in combination with lamivudine and zidovudine versus lamivudine and zidovudine alone in HIV-1-infected antiretroviral-naive adults. Amprenavir PROAB3001 International Study Team. Antivir Ther 5: 215-225.

4. Anonymous. Result summary for PROAB3006. Accessed at Last accessed September 14, 2010.

5. Arvieux C, Tribut O (2005) Amprenavir or fosamprenavir plus ritonavir in HIV infection. Pharmacology, efficacy and tolerability profile. Drugs 65: 633-659.

6. Rodriguez-French A, Boghossian J, Gray GE, Nadler JP, Quinones AR, et al. (2004) The NEAT study: a 48-week open-label study to compare the antivira efficacy and safety of GW433908 versus nelfinavir in antiretroviral therapynaïve HIV-1-infected patients. J Acquir Immune Defic Syndr 35: 22-32.

7. Gathe JC Jr, Ive P, Wood R, Schürmann D, Bellos NC, et al. (2004) SOLO: 48-week efficacy and safety comparison of once-daily fosamprenavir/ritonavir versus twice-daily nelfinavir in naïve HIV-1-infected patients. AIDS 18: 15291537.

8. Smith KY, Weinberg WG, DeJesus E, Fischl MA, Liao Q, et al. (2008) Fosamprenavir or atazanavir once daily boosted with ritonavir $100 \mathrm{mg}$, plus tenofovir/emtricitabine, for the initial treatment of HIV infection: 48-week results of ALERT. AIDS Res Ther 5: 1-10.

9. Hicks CB, DeJesus E, Sloan LM, Sension MG, Wohl DA, et al. (2009) Comparison of once-daily fosamprenavir boosted with either 100 or $200 \mathrm{mg}$ of ritonavir in combination with abacavir-lamivudine: 96-week results from COL100758. AIDS Res Hum Retrovir 25: 395-403.

10. GlaxoSmithKline Clinical Trial Registry. APV30003 (CONTEXT) (2005) A phase III, randomized, multicenter, parallel-group, open-label, three-arm study to compare the efficacy and safety of two dosing regimens of GW433908/ ritonavir $(700 \mathrm{mg} / 100 \mathrm{mg}$ twice daily or $1400 \mathrm{mg} / 200 \mathrm{mg}$ once daily) versus lopinavir/ritonavir $(400 \mathrm{mg} / 100 \mathrm{mg}$ twice daily) for 48 weeks in protease inhibitor experienced HIV-infected adults experiencing virological failure.

11. Wood R, Arasteh K, Stellbrink H-J, Teofilo E, Raffi F, et al. (2004) Six-week randomized controlled trial to compare the tolerabilities, pharmacokinetics, and antiviral activities of GW433908 and amprenavir in human immunodeficiency virus type 1-infected patients. Antimicrob Agents Chemother 48: 116-123.

12. Rodriguez A, Johnson J, Bartlett JA, Herrera G, Sosa N, et al. (2004) Efficacy and safety of switch to GW433908/ritonavir $200 \mathrm{mg}$ (908/r) QD in subjects initiating therapy with amprenavir/ritonavir $200 \mathrm{mg}$ (APV/r) QD: ESS40001 (CLASS). XV International AIDS Conference; Bangkok, Thailand.

13. Bartlett JA, Johnson J, Herrera G, Sosa N, Rodriguez A, et al. (2006) Long-term results of initial therapy with abacavir and lamivudine combined with efavirenz, amprenavir/ritonavir, or stavudine. J Acquir Immune Defic Syndr 43: 284-292.

14. Goujard C, Bernard N, Sohier N, Peyramond D, Lançon F, et al. (2003) Impact of a patient education program on adherence to HIV medication: a randomized clinical trial. J Acquir Immune Defic Syndr 34: 191-194.

15. Hawkins $T$ (2010) Understanding and managing the adverse effects of antiretroviral therapy. Antivir Res 85: 201-209.

16. Anonymous. Result summary for APV10022. Accessed at Last accessed September 14, 2009.

17. Giorgi JV, Hultin LE, McKeating JA, Johnson TD, Owens B, et al (1999) Shorte survival in advanced human immunodeficiency virus type 1 infection is more closely associated with $\mathrm{T}$ lymphocyte activation than with plasma virus burden or virus chemokine coreceptor usage. J Infect Dis 179: 859-870.

18. Sousa AE, Carneiro J, Meier-Schellersheim M, Grossman Z, Victorino RMM (2002) CD4 T cell depletion is linked directly to immune activation in the pathogenesis of HIV-1 and HIV-2 but only indirectly to the viral load. J Immuno 169: 3400-3406.

19. Deeks SG, Kitchen CMR, Liu L, Guo H, Gascon R, et al (2004) Immune activation set point during early HIV infection predicts subsequent CD4+ T-cell changes independent of viral load. Blood.104: 942-947.

20. Hunt PW, Brenchley J, Sinclair E, McCune JM, Roland M et al (2008) Relationship between T cell activation and CD4+ T cell count in HIV-seropositive individuals with undetectable plasma HIV-RNA levels in the absence of therapy. J Infect Dis 197: 126-133. 